\title{
The role of complement in the modulation by fluid-phase IgG of the production of reactive oxygen species by polymorphonuclear leukocytes stimulated with IgG immune complexes
}

S. Chedraoui-Silva and B. Mantovani
Departamento de Bioquímica e Imunologia,

Faculdade de Medicina de Ribeirão Preto,

Universidade de São Paulo, Ribeirão Preto, SP, Brasil

\section{Correspondence \\ B. Mantovani \\ Departamento de Bioquímica \\ e Imunologia, FMRP, USP \\ 14049-900 Ribeirão Preto, SP \\ Brasil \\ Fax: +55-16-633-6840 \\ E-mail: bmantova@fmrp.usp.br}

Research supported by FAPESP and FAEPA.

Received December 13, 2002 Accepted July 31, 2003

\begin{abstract}
The production of reactive oxygen species (ROS) by polymorphonuclear leukocytes (PMN) can be induced by immune complexes and is an important component of phagocytosis in the killing of microorganisms, but can also be involved in inflammatory reactions when immune complexes are deposited in tissues. We have observed that fluid-phase IgG can inhibit the generation of ROS by rabbit PMN stimulated with precipitated immune complexes of $\operatorname{IgG}(\mathrm{ICIgG})$ in a dose-dependent manner, acting as a modulatory factor in the range of physiological $\mathrm{IgG}$ concentrations. This inhibitory effect is compatible with the known affinity (Kd) of monomeric IgG for the receptors involved (FcRII and FcRIII). The presence of complement components in the immune complexes results in a higher stimulation of ROS production. In this case, however, there is no inhibition by fluid-phase $\mathrm{IgG}$. The effect of complement is strongly dependent on the presence of divalent cations $\left(\mathrm{Ca}^{2+}\right.$ or $\left.\mathrm{Mg}^{2+}\right)$ in the medium, whereas the stimulation of ICIgG (without complement) does not depend on these cations. We have obtained some evidence indicating that $\mathrm{iC} 3 \mathrm{~b}$ should be the component involved in the effect of complement through interaction with the $\mathrm{CR} 3$ receptor. The absence of the inhibitory effect of fluid-phase IgG in ROS production when complement is present in the immune complex shows that complement may be important in vivo not only in the production of chemotactic factors for PMN, but also in the next phase of the process, i.e., the generation of ROS.
\end{abstract}

Key words

- Polymorphonuclear

leukocytes

- Reactive oxygen species

- Immune complex

$\cdot \lg G$

- Complement

\section{Introduction}

It is well known that polymorphonuclear leukocytes (PMN) can undergo a rapid metabolic change, known as the respiratory burst, when exposed to a variety of stimuli (1); this includes an increased rate of oxygen con- sumption, a marked activation of the pentose-phosphate pathway and the generation of reactive oxygen species (ROS; $\mathrm{O}_{2}^{-}, \mathrm{H}_{2} \mathrm{O}_{2}$, $\mathrm{OH}^{*}$, singlet oxygen, etc.). The production of these highly reactive compounds which have microbicidal properties is a component of the process of phagocytosis, being thus im- 
plicated in the mechanisms of defense. However, in some instances it may be involved in inflammatory reactions, since these compounds may be released from the cells and contribute to tissue damage (2).

It is well established that the interaction of particles or surfaces with leukocytes mediated by Fc $\gamma$ receptors (immune complexes of $\mathrm{IgG}$ - ICIgG) can trigger the respiratory burst. However, divergent findings have been reported as to the ability of complement (C3b and iC3b) to induce the generation of ROS upon interaction with the cells. Some experiments have shown that $\mathrm{C} 3 \mathrm{~b}$ or $\mathrm{iC} 3 \mathrm{~b}$ is not able to induce the generation of ROS by human monocytes and PMN (3); other observations, however, have indicated an active role of these complement components in triggering the respiratory burst $(4,5)$. Also, some evidence has been presented indicating that the production of ROS by PMN is dependent on a synergic mechanism involving Fc $\gamma$ and complement receptors (6).

Regardless of the importance of determining which kind of receptors are able to trigger this mechanism by themselves, another relevant issue is to know the behavior of these cells in the production of these compounds under physiological conditions, when the phagocytes interact with immune complexes which contain IgG or IgG and complement components, since in vivo there is a high concentration of fluid-phase $\operatorname{IgG}$ which possibly could compete for the Fc $\gamma$ receptors. We analyze this question by in vitro experiments with rabbit PMN using as a stimulus two types of immune complexes in the form of precipitates: ICIgG and ovalbumin and the same immune complexes with complement components incorporated by previous incubation with whole serum (ICIgG-C).

\section{Material and Methods}

The preparation of the antigen (chicken ovalbumin), the purification of rabbit $\mathrm{IgG}$ anti-ovalbumin antibodies, the preparation of ICIgG with ovalbumin in the equivalence zone, as well as the isolation of rabbit blood PMN were performed as described (7).

\section{Media and solutions}

Phosphate-buffered saline (PBS) containing $0.9 \% \mathrm{NaCl}$ and $8 \mathrm{mM}$ sodium phosphate buffer, $\mathrm{pH}$ 7.2, was used. Hanks' medium was prepared as described (8). Luminol (Sigma, St. Louis, MO, USA) was dissolved in dimethylsulfoxide (DMSO) at a concentration of $2 \mathrm{mM}$; for the experiments this stock solution was diluted with Hanks' medium (the final concentration of DMSO was $0.45 \%, \mathrm{v} / \mathrm{v})$.

\section{Animals}

New Zealand rabbits were used as blood donors for the isolation of PMN as well as of normal or immune serum.

\section{Preparation of antigen-antibody-complement complexes}

Immune complexes of ovalbumin and $\mathrm{IgG}$ antibodies were prepared at equivalence (7). Complement was added to ICIgG for the preparation of the ICIgG-C complexes as follows: after centrifugation and washing three times with PBS, the antigen-antibody precipitates were incubated with fresh rabbit serum at the proportion of $182 \mu \mathrm{g}$ of immune complex per $\mathrm{ml}$ of serum for $30 \mathrm{~min}$ at $37^{\circ} \mathrm{C}$ $(7,9)$. The immune precipitates were then washed three times with PBS by centrifugation at $4^{\circ} \mathrm{C}$ and resuspended in Hanks' medium containing $15 \mathrm{mM}$ HEPES, $\mathrm{pH}$ 7.2, and $0.1 \%$ gelatin. The quantity of immune complexes is always reported as the mass of protein before the addition of complement. Protein concentrations in the immune precipitates were determined by the micro-biuret method. We found that after formation of ICIgG-C the mass of the immune complex 
increased by $44 \%$. To test for the complement-fixing capacity of the ICIgG, the residual $\mathrm{CH}_{50}(50 \%$ hemolytic unit of complement) was determined (10) in the supernatant after incubation of the immune complexes with serum. It was found that $182 \mu \mathrm{g}$ of ICIgG consumed $29.8 \mathrm{CH}_{50}$ units.

\section{Treatment of rabbit serum to inactivate some complement components}

Rabbit serum used as a source of complement was subjected to three types of treatment in order to selectively inactivate complement components: a) heat inactivation at $56^{\circ} \mathrm{C}$ for $30 \mathrm{~min}$ to block the activity of $\mathrm{C} 1$, $\mathrm{C} 2$ and factor $\mathrm{B}$; b) depletion of $\mathrm{C} 3$ by treatment of serum with zymosan using 15 $\mathrm{mg}$ of zymosan per $\mathrm{ml}$ of serum at $37^{\circ} \mathrm{C}$ for $1 \mathrm{~h}(10)$; c) inactivation of $\mathrm{C} 3$ and $\mathrm{C} 4$ by treatment of serum with $50 \mathrm{mM}$ hydrazine, incubated with serum at $37^{\circ} \mathrm{C}$ for $2 \mathrm{~h}$, followed by dialysis with PBS containing $\mathrm{Ca}^{2+}$ and $\mathrm{Mg}^{2+}$ at the concentrations of Hanks' medium (11).

\section{Measurement of the production of ROS by chemiluminescence}

The production of ROS by PMN was assayed by the generation of chemiluminescence in the presence of luminol (12). This is an indirect measurement of the amount of superoxide produced: the stimulation of the cells leads to the activation of NADPH oxidase, resulting in the formation of $\mathrm{O}_{2}^{-}$which, upon the action of superoxide dismutase (SOD), undergoes a dismutation to $\mathrm{H}_{2} \mathrm{O}_{2}$ which, in the presence of $\mathrm{Cl}^{-}$and myeloperoxidase, forms $\mathrm{OCl}^{-}$. Some of these compounds react with luminol bringing the molecule to an excited state whose decay results in light emission (13). The kinetics of chemiluminescence was recorded with a BioOrbit luminometer, model 1251 (Bio-Orbit Oy, Turku, Finland). PMN suspensions $\left(10^{6}\right.$ cells $)$ in Hanks' medium containing $15 \mathrm{mM}$
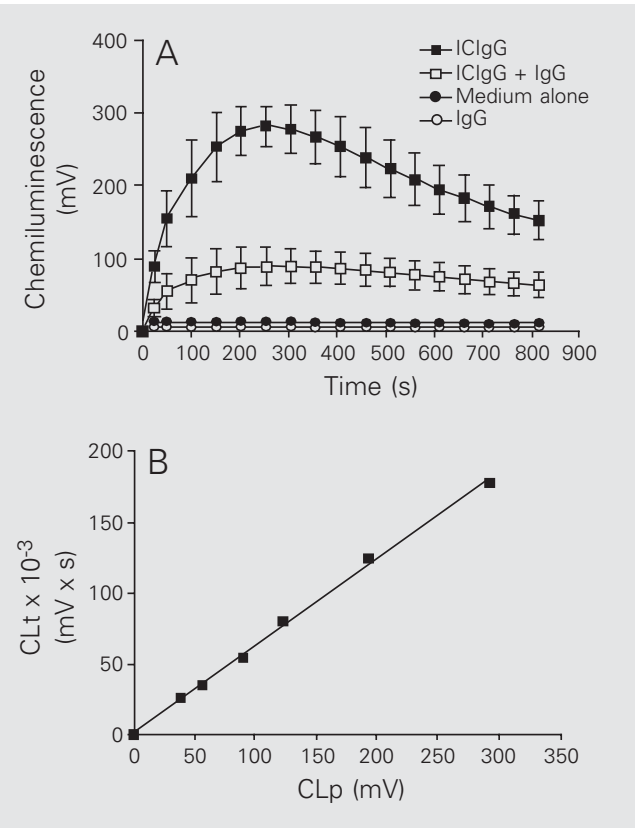

HEPES, pH 7.2, $0.1 \%$ gelatin and $10 \mu \mathrm{M}$ luminol were added to the cuvettes and preincubated for $15 \mathrm{~min}$ at $37^{\circ} \mathrm{C}$. The cuvettes were then inserted into the luminometer, and the stimulus (immune complex) was added to start the experiment; the final volume was $1.1 \mathrm{ml}$. The cuvettes were maintained at $37^{\circ} \mathrm{C}$ and the rate of photon emission (reported in $\mathrm{mV}$ ) was recorded every $51 \mathrm{~s}$. The first measurement was made after $25 \mathrm{~s}$.

\section{Competition experiments with fluid-phase IgG}

PMN suspensions were preincubated with fluid-phase IgG at $37^{\circ} \mathrm{C}$ for 15 min in Hanks' medium with the desired concentrations of IgG before stimulation with the immune complexes, also in the presence of IgG. The IgG solution used (prepared by DEAE cellulose chromatography) was tested for the presence of aggregated molecules by polyacrylamide gel electrophoresis using 3.5\% acrylamide gels with $0.5 \%$ agarose as described previously (14), and no aggregation was found. In addition we demonstrated that centrifugation of $\mathrm{IgG}$ solution at $100,000 \mathrm{~g}$ for $30 \mathrm{~min}$ just before these experiments had no appre-
Figure 1. Kinetics of chemiluminescence, a measure of the rate of reactive oxygen species production, by rabbit polymorphonuclear leukocytes stimulated with IgG immune complexes $(\mathrm{IClgG})$ in the absence and in the presence of fluid-phase IgG. $A$, Cells $\left(10^{6}\right)$ were preincubated in Hanks' medium alone or containing $10 \mathrm{mg} / \mathrm{ml} \mathrm{lgG}$ for $15 \mathrm{~min}$ at $37^{\circ} \mathrm{C}$ and then stimulated with $300 \mu \mathrm{g} \mathrm{IClgG}$. Chemiluminescence was recorded in a final volume of $1.1 \mathrm{ml}$. Two controls are shown: only cells (medium alone) and cells plus $10 \mathrm{mg} / \mathrm{ml}$ $\operatorname{lgG}(\operatorname{lgG})$. Data are reported as means $\pm S D$ for $N=4$ (cells from different animals). B, Correlation between chemiluminescence in the peak (CLp) and total chemiluminescence (CLt) for 13.6 min (calculated by integration of the peak). The six points correspond to six different concentrations (9.4 to $300 \mu \mathrm{g} / \mathrm{ml}$ ) of IClgG. Each point corresponds to the mean value of 4 independent experiments (different animals). 
Figure 2. Inhibition of reactive oxygen species production by increasing concentrations of fluidphase IgG. Cells $\left(10^{6}\right)$ were preincubated with fluid-phase IgG for $15 \mathrm{~min}$ at $37^{\circ} \mathrm{C}$ and then stimulated with $300 \mu \mathrm{g} \mathrm{IClgG}$. The control cells were preincubated in the medium without IgG. Results are reported as percent chemiluminescence in the peak in relation to control values (mean $\pm \mathrm{SD}, \mathrm{N}=4$ with cells from different animals)

Figure 3. Effect of complement components incorporated into immune complexes of $\mathrm{lgG}$ (IClgG-C) on the stimulation of reactive oxygen species production by polymorphonuclear leukocytes and the influence of the presence of fluid-phase IgG. Cells $\left(10^{6}\right)$ were preincubated in Hanks' medium with or without $10 \mathrm{mg} / \mathrm{ml}$ fluid-phase lgG for 15 min at $37^{\circ} \mathrm{C}$ before stimulation with different amounts of immune complexes. For IClgG-C the mass of immune complexes indicated on the abscissa corresponds to its mass before the addition of complement. IClgG$\mathrm{C}$ was prepared using $182 \mu \mathrm{g}$ IClgG per ml of serum. Data are reported as means \pm SEM for $\mathrm{N}$ $=4$ (different animals).
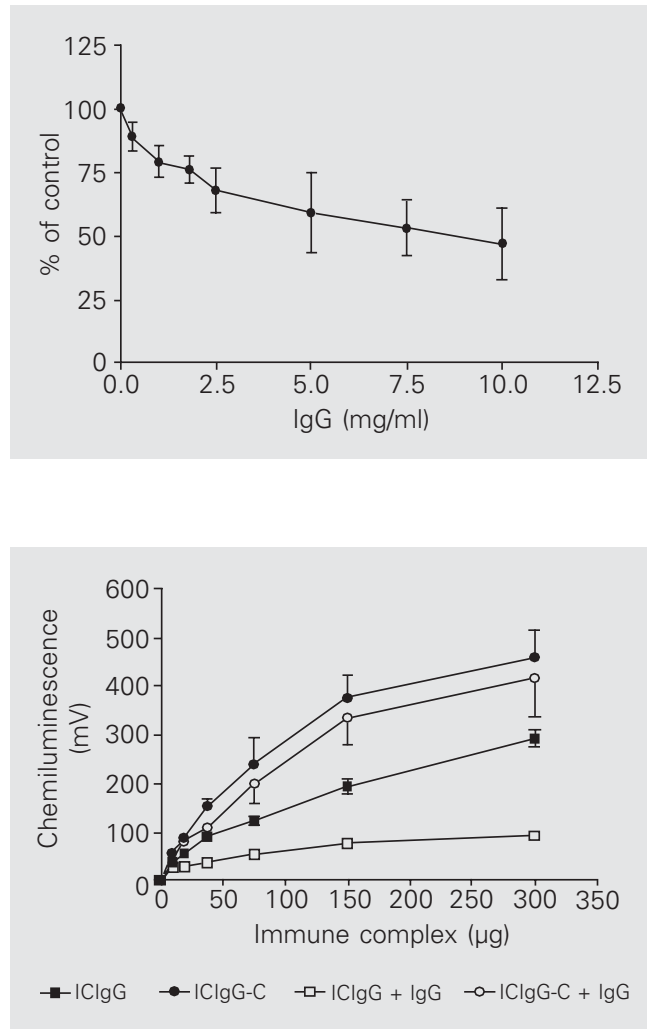

ciable effect on the inhibitory action of fluidphase IgG on ROS production by PMN stimulated with ICIgG. In view of this result, this previous centrifugation was performed in some, but not all, experiments.

\section{Results}

The kinetics of chemiluminescence production by PMN induced by ICIgG is presented in Figure 1A. The presence of fluidphase IgG at a concentration representative of that existing in plasma $(10 \mathrm{mg} / \mathrm{ml})$ greatly reduced the stimulatory effect of the immune complex. The chemiluminescence with PMN alone as well as with PMN plus $10 \mathrm{mg} /$ $\mathrm{ml}$ fluid-phase IgG was very low and negligible compared with that induced by the immune complex. Figure 1B shows the correlation between the values of chemiluminescence in the peak and the total chemiluminescence after $13.6 \mathrm{~min}$ (calculated by integration over this period of time) using six different concentrations of ICIgG (from 9.4 to $300 \mu \mathrm{g} / \mathrm{ml})$. Since there was a close correlation between the two measurements, we used only the chemiluminescence in the peak, that corresponds to the maximum rate of ROS production, for quantification in the subsequent experiments.

Figure 2 shows the inhibitory effect of increasing concentrations of fluid-phase IgG on the stimulation of ROS production by PMN induced by ICIgG $(300 \mu \mathrm{g} / \mathrm{ml})$. The inhibition was progressive with increasing IgG concentration and started to be demonstrable at around $0.9 \mathrm{mg} / \mathrm{ml} \mathrm{IgG;} \mathrm{with} 10 \mathrm{mg}$ / $\mathrm{ml} \mathrm{IgG} \mathrm{the} \mathrm{effect} \mathrm{reported} \mathrm{as} \mathrm{percent} \mathrm{of}$ control (without fluid-phase IgG) was in the range of 34 to $64 \%$ in four independent experiments $(47 \pm 14 \%$, mean $\pm \mathrm{SD})$.

In another set of experiments we analyzed the possible effect of complement incorporated into the immune complex of $\operatorname{IgG}$ on its stimulatory effect on ROS production, as well as the susceptibility to inhibition by the soluble immunoglobulin, using several immune complex concentrations (Figure 3). In the range of immune complex concentrations from 9.4 to $300 \mu \mathrm{g} / \mathrm{ml}$, the presence of $\mathrm{IgG}$ greatly reduced ROS production by ICIgG; however, when complement was present in the immune complex, no inhibition was observed. The stimulatory effect of ICIgG-C was higher than the effect of ICIgG, albeit it was not affected by the presence of soluble IgG (the two curves were practically coincident in the entire range of immune complex concentrations).

The experiments in Figure 4 show the influence of extracellular divalent cations $\left(\mathrm{Ca}^{2+}\right.$ and $\left.\mathrm{Mg}^{2+}\right)$ on ROS production induced by ICIgG and ICIgG-C. For each type of immune complex the control was the value of chemiluminescence in the peak obtained in complete Hanks' medium $\left(1.26 \mathrm{mM} \mathrm{Ca}{ }^{2+}\right.$ and $0.9 \mathrm{mM} \mathrm{Mg}^{2+}$ ).

Stimulation with ICIgG was practically independent of the presence of these cations in the medium. The effect of ICIgG-C, how- 
ever, was strongly dependent on them, with $\mathrm{Ca}^{2+}$ alone being sufficient for the full effect, whereas $\mathrm{Mg}^{2+}$ produced a lower stimulation (around $60 \%$ of control). Moreover, when fluid-phase $\mathrm{IgG}$ was present $(10 \mathrm{mg} / \mathrm{ml})$ the same dependence on $\mathrm{Ca}^{2+}$ and $\mathrm{Mg}^{2+}$ was obtained for the effect of ICIgG-C.

In order to have some indication of which components of complement incorporated into the immune complex were responsible for the effect of ICIgG-C, we prepared this immune complex using as a source of complement rabbit serum previously treated by three different procedures: heat inactivation at $56^{\circ} \mathrm{C}$ for 30 min blocking the activity of $\mathrm{C} 1, \mathrm{C} 2$ and factor $\mathrm{B}$, depletion of $\mathrm{C} 3$ by treatment with zymosan, and inactivation of $\mathrm{C} 3$ and $\mathrm{C} 4$ by treatment with hydrazine. The experiments in Figure 5 were done in the presence of $10 \mathrm{mg} / \mathrm{ml}$ fluid-phase $\mathrm{IgG}$.

All three treatments abolished the effect of complement (in these experiments the control was the effect of ICIgG without competition with soluble IgG). These results indicate that $\mathrm{iC} 3 \mathrm{~b}$ must be involved in the effect of complement incorporated into immune complexes.

\section{Discussion}

Fc $\gamma$ receptors, which recognize the $\mathrm{Fc}$ domain of $\mathrm{IgG}$, are involved in a number of cellular functions such as phagocytosis, superoxide production and cytokine release. Three types of $\mathrm{Fc} \gamma$ receptors have been described in human and mouse PMN: FcRI, FcRII and FcRIII (15). FcRI is a high affinity receptor for monomeric IgG with a dissociation constant ranging from 10 to $0.1 \mathrm{nM}$, and is expressed in INF- $\gamma$-treated neutrophils. FcRII and FcRIII are normally present in non-activated PMN and have a lower affinity for $\mathrm{IgG}$, with a dissociation constant ranging from 10 to $0.1 \mu \mathrm{M}$ (16-18). The same types of receptors may be present in rabbit PMN. Thus, in our experiments the low affinity receptors FcRII and FcRIII might

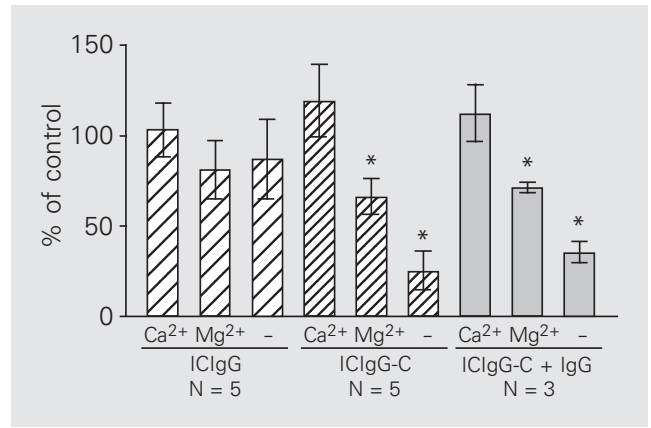

mediate the interaction between ICIgG and the cells. In competition experiments using $10 \mathrm{mg} / \mathrm{ml}$ fluid-phase IgG we had an IgG concentration of $67 \mu \mathrm{M}$, a value in the range of the dissociation constant for FcRII and FcRIII (10 to $0.1 \mu \mathrm{M})$. It is thus reasonable to assume that fluid-phase $\mathrm{IgG}$ could compete with the immune complexes for the binding to the receptors, resulting in partial inhibition of the stimulation of ROS production, as observed here.

We have shown that the presence of complement components in the immune complexes of $\operatorname{IgG}$ appreciably increases the capacity of ROS production by PMN. Also, when complement is present in the immune complexes, fluid-phase IgG has no effect on the induction of ROS production. Complement receptors would not be affected by the occupation of Fc $\gamma$ receptors by fluid-phase $\mathrm{IgG}$, so that the ICIgG-C can by-pass the competitive inhibition that is observed with ICIgG. In this case, the interaction mediated by complement receptors may increase the binding of immune complexes to the cells or may by itself also stimulate ROS generation.

One possibility we should consider is that the immune complex could be partially solubilized upon the addition of serum for the preparation of ICIgG-C, as previously reported $(19,20)$. In our experiments this was improbable since the relation between serum volume and the ICIgG mass used by us was much smaller than that needed to solubilize the immune complexes. Compared to the volume used by the cited investigators with IgG antibody and BSA, we used a se-
Figure 4. Effect of extracellular $\mathrm{Ca}^{2+}$ and $\mathrm{Mg}^{2+}$ on reactive oxygen species production induced by IClgG and IClgG-C. Polymorphonuclear leukocytes $\left(10^{6}\right.$ cells) were suspended in Hanks' medium without $\mathrm{Ca}^{2+}$ and $\mathrm{Mg}^{2+}$ $(-)$, or in medium containing either one of these cations at the concentrations used in Hanks' medium (1.26 $\mathrm{mM} \mathrm{Ca}^{2+}$ and 0.9 $\mathrm{mM} \mathrm{Mg}{ }^{2+}$. The chemiluminescence in the peak with $300 \mu \mathrm{g}$ IClgG was measured and the results are indicated as \% of control; for each of the three groups the control value was that obtained with complete Hanks' medium. IClgG-C + IgG indicates the experiments in the presence of $10 \mathrm{mg} / \mathrm{ml}$ fluidphase IgG. The values obtained with only $\mathrm{Ca}^{2+}$ in the medium were not statistically different from the corresponding controls (with $\mathrm{Ca}^{2+}$ and $\mathrm{Mg}^{2+}$ ). Data are reported as means $\pm \mathrm{SEM}$. ${ }^{*} \mathrm{P}<$ 0.02 for comparison of the conditions with $\mathrm{Mg}^{2+}$ or (-) with the corresponding values with $\mathrm{Ca}^{2+}$ in each of the three groups ( $t$ test).

Braz J Med Biol Res 36(12) 2003 
Figure 5. Effect of three kinds of treatment of rabbit serum used as a source of complement in the preparation of IClgG-C on the experiments of competition with fluid-phase IgG. Polymorphonuclear leukocytes $\left(10^{6}\right.$ cells) were stimulated with the immune complexes $(300 \mu \mathrm{g})$ and the chemiluminescence in the peak was recorded (general conditions were the same as described in previous experiments). The values presented were obtained in the presence of $10 \mathrm{mg} / \mathrm{ml}$ fluid-phase $\mathrm{lgG}$, and are reported as percent of control (the chemiluminescence in the peak obtained with IClgG without fluid-phase $\operatorname{lgG}$ ). Serum treatments: $\mathrm{H}=$ treatment with hydrazine, Heat $=$ incubation at $56^{\circ} \mathrm{C}$ for $30 \mathrm{~min}, \mathrm{~T}=$ the same conditions for treatment with hydrazine but without this reagent, $Z$ = absorption with zymosan. Data are reported as means \pm SEM for $\mathrm{N}=4-6$ with different cell preparations (with the exception of $\mathrm{H}$ and $\mathrm{T}$ in which 2 cell preparations were used $(2$ determinations for each one). ${ }^{*} \mathrm{P}<0.004$ compared to IClgG-C (t-test).

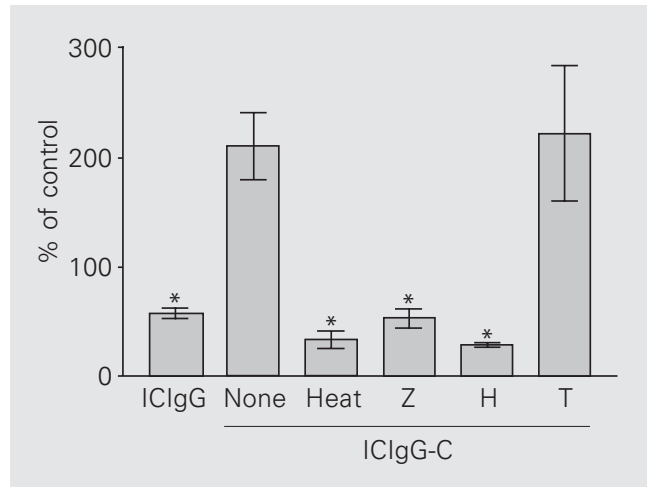

rum volume about 18 to 20 times smaller than that required for solubilization. But, even in the case of a small amount of immune precipitate being solubilized (despite the increase in mass of the immune complex by incorporation of complement components), this does not interfere with the interpretation of the results since ICIgG-C induces a higher ROS production than ICIgG (obviously it would interfere if the reverse were obtained).

It is known that, upon activation of the complement system by immune complexes, several activated proteins (derived from $\mathrm{C} 1$, $\mathrm{C} 4, \mathrm{C} 2$, and $\mathrm{C} 3$ ) become tightly bound to the complexes $(9,21,22)$. PMN have been shown to have receptors for some of these components which may be involved in various biological functions (23). Thus, interaction through $\mathrm{C} 3 \mathrm{~b} / \mathrm{iC} 3 \mathrm{~b}$ can promote the binding of immune complexes; it was shown, however, that the interaction through $\mathrm{C} 3 \mathrm{~b}$ and iC3b cannot induce phagocytosis (24). C1q bound to latex beads stimulates the respiratory burst and the hexose phosphate pathway in these cells (25). As to the capacity of C3b/ $\mathrm{iC} 3 \mathrm{~b}$ to trigger the generation of ROS, some studies have led to conflicting results (3-6). Possibly the differences in physical form of the stimulus could explain these differences. None of these studies on the function of complement receptors used precipitated immune complexes as done in our experiments, a fact that might be important in inflammatory reactions involving PMN. Our finding that complement can reverse the inhibition by fluid-phase IgG suggests that its components incorporated into the immune complexes could have a stimulatory effect by themselves. However, one cannot exclude the possibility that $\mathrm{Fc}$ receptors could be involved because, if complement promotes the binding of the immune complex to the cell membrane, the IgG molecules present in the immune precipitate would be forced to interact with its receptors and the Fc-mediated triggering of stimulation would be feasible.

We have observed that the effects of the presence of complement in the immune complexes on ROS generation are strongly dependent on divalent cations $\left(\mathrm{Ca}^{2+}\right.$ or $\left.\mathrm{Mg}^{2+}\right)$, whereas the stimulation of ROS production by ICIgG practically does not require these cations in the medium. This is evidence for the involvement of other kinds of receptors (CR3 and CR4 which bind to iC3b or CR1 which binds to $\mathrm{C} 3 \mathrm{~b}$ ). This is consistent with the observation that neutrophil activation by IgG immune complexes was less dependent on extracellular $\mathrm{Ca}^{2+}$ than that induced by C5a (26).

It is interesting to note that in the experiments with $\mathrm{Ca}^{2+}$ and $\mathrm{Mg}^{2+}$ (Figure 4) the effect of ICIgG-C in the absence of these cations was very low even without $\operatorname{IgG}$ in the fluid phase. At first this would not have been expected since $\mathrm{IgG}$ is present in the immune complex and could interact with $\mathrm{Fc} \gamma$ receptors, and this interaction, as shown in the same experiment, does not depend on these ions. One possible explanation would be that the incorporation of complement into ICIgG blocks to some extent the binding site for the receptor in the Fc domains. This is plausible since it was found that FcRII and FcRIII bind to $\mathrm{IgG}$ in the lower hinge region (27), which is also close to the site of fixation of $\mathrm{C} 1 \mathrm{q}$ to the immunoglobulin (28).

The experiments illustrated in Figure 5, in which the serum used as a source of complement was subjected to some treat- 
ments in order to selectively inhibit complement components, indicate that the components involved in the interaction of ICIgG-C with PMN should be $\mathrm{C} 3 \mathrm{~b}$ (involving CR1) or iC3b (involving CR3 and CR4). The direct participation of $\mathrm{C} 1 \mathrm{q}$, for which there is a specific receptor in PMN (25), may be excluded since treatment with hydrazine or absorption of serum with zymosan does not interfere with this component. It is most likely that iC $3 b$ may be responsible for the binding to the cells, since $\mathrm{C} 3 \mathrm{~b}$ (which binds to CR1) has a half-life of about $90 \mathrm{~s}$ (29) and, in the preparation of ICIgG-C, ICIgG was incubated with serum for $30 \mathrm{~min}$. So, the receptor involved should be CR3. Further evidence for excluding CR1 in the interaction is that, although this receptor can also recognize $\mathrm{iC} 3 \mathrm{~b}$, it does not require divalent cations for binding (15). It is also interesting to note that CR3 has a long extracellular domain containing three calmodulin-like consensus $\mathrm{Ca}^{2+}$-binding sequences (30), in agreement with the effect of this cation in our experiments.

It is known that PMN can migrate to diverse sites of the organism where variable concentrations of IgG might exist. Thus we may say that the fluid-phase $\operatorname{IgG}$ present at these sites can exert an important modulation of the process of ROS production by PMN induced by IgG immune precipitates.

PMN have been implicated in many diseases as possible mediators of tissue damage. The production of ROS by these cells upon stimulation may be one of the mechanisms involved in this effect (2). Since ICIgG is a powerful stimulant of ROS generation, it is possible that the formation of these compounds by PMN could be involved in several pathological states dependent on deposition of ICIgG on tissues. Complement has been implicated in several conditions of tissue injury induced by immune complexes (3133 , although it may not be necessary, depending on the animal species and tissue site $(34,35)$. It has been well established that activation of complement results initially in the production of the potent chemotactic molecule (C5a) which promotes PMN recruitment to sites of inflammation (36). Our results indicate another important role for complement mediated by the incorporation of its components into ICIgG in the next phase of the process, i.e., the stimulation of ROS production. Although the presence of complement in the immune complex may not be an absolute requirement for this function (because the competition by physiological concentrations of $\mathrm{IgG}$ in tissue fluids cannot be complete), it is quantitatively most relevant. This result is also consistent with previous observations (37) showing the same important role of complement in the induction of lysosomal enzyme release by PMN, which might be another factor involved in inflammatory reactions.

\section{Acknowledgments}

The authors thank Dr. Victor Diaz Galban for valuable help with graphic computation, Maria Thereza Rodrigues for expert secretarial assistance, and José Antonio da Silva for technical assistance.

\section{References}

1. Seifert R \& Schultz G (1991). The superoxide-forming NADPH oxidase of phagocytes. An enzyme system regulated by multiple mechanisms. Reviews of Physiology, Biochemistry and Pharmacology, 117: 5-17.

2. Halliwell B \& Gutteridge JMC (1995). Free Radicals in Biology and Medicine. 2nd edn. Oxford Clarendon Press, Oxford, UK, 416-508.
3. Wright SD \& Silverstein SC (1983). Receptors for C3b and C3bi promote phagocytosis but not the release of toxic oxygen from human phagocytes. Journal of Experimental Medicine, 158: 20162023.

4. Gordon DL, Krueger RA, Quie PG \& Hostetter MK (1985). Amidation of $\mathrm{C} 3$ at the thiolester site: stimulation of chemiluminescence and 
phagocytosis by a new inflammatory mediator. Journal of Immunology, 134: 3339-3345.

5. Hoogerwerf M, Weening RS, Hack CE \& Ross D (1990). Complement fragments $\mathrm{C} 3 \mathrm{~b}$ and $\mathrm{iC} 3 \mathrm{~b}$ coupled to latex induce a respiratory burst in human neutrophils. Molecular Immunology, 27: 159-167.

6. Zhou M \& Brown EJ (1994). CR3 (Mac-1, $\alpha_{m} \beta_{2}$, CD11b/CD18) and FC $\gamma$-RIII cooperate in generation of a neutrophil respiratory burst: requirement for Fc $\gamma$-RII and tyrosine phosphorylation. Journal of Cell Biology, 125: 1407-1416.

7. Lucisano YM \& Mantovani B (1984). Lysosomal enzyme release from polymorphonuclear leukocytes induced by immune complexes of IgM and of IgG. Journal of Immunology, 132: 2015-2020.

8. Paul J (1970). Cell and Tissue Culture. 4th edn. E. \& S. Livingstone, Edinburgh and London, 86-119.

9. Gadd KJ \& Reid KB (1981). The binding of complement component C3 to antibody-antigen aggregates after activation of the alternative pathway in human serum. Biochemical Journal, 195: 471-480.

10. Kabat EA \& Mayer MM (1971). Experimental Immunochemistry. 2nd edn. Charles C. Thomas, Springfield, IL, USA, 133-240.

11. Harrison RA \& Lachmann PJ (1986). Complement technology. In: Weir DM (Editor), Handbook of Experimental Immunology. 4th edn. Vol. 1. Blackwell Scientific Publications, Oxford, UK, 39.1-39.49.

12. Williams AJ \& Cole PJ (1981). The onset of polymorphonuclear leukocyte membrane-stimulated metabolic activity. Immunology, 43: 733-739.

13. De Chatelet LR, Long GD, Shirley PS, Bass DA, Thomas MJ, Henderson FW \& Cohen MS (1982). Mechanism of the luminol-dependent chemiluminescence of human neutrophils. Journal of Immunology, 129: 1589-1593.

14. Kurlander RJ \& Batker J (1982). The binding of human immunoglobulin G1 monomer and small, covalently cross-linked polymers of immunoglobulin $\mathrm{G} 1$ to human peripheral blood monocytes and polymorphonuclear leukocytes. Journal of Clinical Investigation, 69: 1-8.

15. Greenberg S \& Silverstein SC (1993). Phagocytosis. In: Paul WE (Editor), Fundamental Immunology. 3rd edn. Raven Press, New York, 941-964

16. Hulett MD \& Hogarth PM (1994). Molecular basis of Fc receptor function. Advances in Immunology, 57: 1-127.

17. Galon J, Robertson MW, Galinha A, Mazieres N, Spagnoli R, Fridman WH \& Sautes C (1997). Affinity of the interaction between Fc gamma receptor type III (FcyRIII) and monomeric human IgG subclasses. Role of FcyRIII glycosylation. European Journal of Immunology, 27: 1928-1932.

18. Powell MS, Barton PA, Emmanouilidis D, Wines BD, Newmann GM, Peitersz GA, Maxwell KF, Garrett TP \& Hogart PM (1999). Biochemical analysis and crystallisation of FC gamma RIla, the low affinity receptor for lgG. Immunology Letters, 68: 17-23.

19. Czop J \& Nussenzweig $V$ (1976). Studies on the mechanism of solubilization of immune precipitates by serum. Journal of Experimental Medicine, 143: 615-630.

20. Takahashi M, Tack BF \& Nussenzweig $V$ (1977). Requirements for the solubilization of immune aggregates by complement. Journal of Experimental Medicine, 145: 86-100.

21. Goers JW \& Porter RR (1978). The assembly of early components of complement on antibody antigen aggregates and on antibody-coated erythrocytes. Biochemical Journal, 175: 675-684.

22. Campbell RD, Dodds AW \& Porter RR (1980). The binding of human complement component $\mathrm{C} 4$ to antibody-antigen aggregates. Biochemical Journal, 189: 67-80.

23. Carrol MC (1998). The role of complement and complement receptors in induction and regulation of immunity. Annual Review of Immunology, 16: 545-568.

24. Mantovani B (1975). Different roles of IgG and complement receptors in phagocytosis by polymorphonuclear leukocytes. Journal of Immunology, 115: 15-17.

25. Tenner AJ \& Cooper NR (1982). Stimulation of a human polymorphonuclear leukocyte oxidative response by the Cla subunit of the first complement component. Journal of Immunology, 128: 25472552.

26. Shirato M, Takahashi K, Nagasawa S \& Koyama J (1988). Different sensitivities of the responses of human neutrophils stimulated with immune complexes and C5a anaphylatoxin to pertussis toxin. FEBS Letters, 234: 231-234.

27. Radaev S \& Sun PD (2001). Recognition of IgG by Fcy receptor. The role of Fc glycosylation and the binding of peptide inhibitors. Journal of Biological Chemistry, 276: 16478-16483.

28. Yasmeen D, Ellerson JR, Dorrington KJ \& Painter RH (1976). The structure and function of immunoglobulin domains. IV. The distribution of some effector functions among the C gamma2 and C gamma3 homology regions of human immunoglobulin G1. Journal of Immunology, 116: 518-526.

29. Ross GP, Walport MJ \& Hogg N (1989). Receptors for lgG FC and fixed C3. In: Zembala M \& Asherson GL (Editors), Human Monocytes. Academic Press, London, UK, 123-139.

30. Arnaout MA, Gupta SK, Pierce MW \& Tenen DG (1988). Amino acid sequence of the alpha subunit of human leukocyte adhesion receptor Mo1 (complement receptor type 3). Journal of Cell Biology, 106: 2153-2158

31. Baumann U, Köhl J, Tschernig T, Schwerter-Strumpf K, Verbeek JS, Schmidt RE \& Gessner JE (2000). A codominant role of Fc $\gamma R \mathrm{RI} / \mathrm{II}$ and $\mathrm{C} 5 \mathrm{aR}$ in the reverse Arthur reaction. Journal of Immunology, 164: 1065-1070

32. Ward PA (1996). Role of complement, chemokines, and regulatory cytokines in acute lung injury. Annals of the New York Academy of Sciences, 796: 104-112.

33. Heller T, Gessner JE, Schmidt RE, Klos A, Bautsch W \& Köhl J (1999). Cutting edge: Fc receptor type I for IgG on macrophages and complement mediate the inflammatory response in immune complex peritonitis. Journal of Immunology, 162: 5657-5661.

34. Sylvestre D, Clynes R, Ma M, Warren H, Carroll MC \& Ravetch JV (1996). Immunoglobulin G-mediated inflammatory responses develop normally in complement-deficient mice. Journal of Experimental Medicine, 184: 2385-2392.

35. Ravetch JV \& Clynes RA (1998). Divergent roles for Fc receptors and complement in vivo. Annual Review of Immunology, 16: 421432.

36. Gerard C \& Gerard NP (1994). C5a anaphylatoxin and its seven transmembrane-segment receptors. Annual Review of Immunology, 12: 775-808.

37. Lucisano YM \& Mantovani B (1988). The role of complement in the stimulation of lysosomal enzyme release by polymorphonuclear leucocytes induced by immune complexes of $\mathrm{lgG}$ and of $\mathrm{lgM}$. Immunology, 65: 171-175. 